\title{
Milton’s Lucretian Anxiety Revisited
}

\author{
KATHERINE CALLOWAY \\ University of British Columbia
}

De récentes études portant sur le traitement de Lucrèce dans Paradise Lost de Milton, montrent que ce dernier s'inquiétait du nihilisme présent dans le De rerum natura de Lucrèce. Le présent article contribue à cet examen, en confrontant le caractère anxieux de Milton avec certains signes que Milton était parfois en accord avec le poète philosophe de l'Antiquité, et en observant que son traitement de Lucrèce ne témoigne pas de plus d'anxiété que son appropriation des sources païennes, bien que son poème rejette clairement la doctrice épicurienne. Milton et Lucrèce réprouvent l'ambition politique et la religion païenne, et cette dernière avec une rhétorique très similaire. En effet, le culte du Moloch décrit par Milton dans Paradise Lost 1, ressemble au sacrifice d'Iphigénie dans De rerum natura 1. De plus, le traitement qu'y fait Milton de l'annihiliation est clairement en contradiction avec Lucrèce : il place systématiquement le discours lucrétien sur la mort dans la bouche de Satan, des démons et des humains déchus. En conséquence, il semble qu'on devrait donner à Lucrèce une place plus assurée en tant que source à laquelle Milton a puisé dans l'élaboration de Paradise Lost, alors que ce dernier devrait être déchargé de cette image qu'on lui attribue de lecteur anxieux de l'auvre de Lucrèce.

Milton and Lucretius set out with a similarity of subject matter, though opposed in design, participating with one another by opposites, as Plato would say. One might paraphrase Milton and state

Lucretius' purpose as "to deny eternal Providence and impugn the ways of the gods to men."

Clyde Murley, $1947^{1}$

$\mathrm{M}$ ilton was worried about the nihilism set forth in Lucretius's De Rerum Natura - or at least this view of him seems to haunt recent work considering Lucretian subject matter in Paradise Lost. The most memorable treatment of Milton's fearfulness is John Leonard's compelling essay "Milton, Lucretius, and 'the Void Profound of Unessential Night," in which Leonard considers Lucretian affinities in Milton's sometimes bright, sometimes dark universe and finds in the poem an "ambivalence about the brightness of our universe" that to his mind "betrays a real anxiety that cannot be explained away ... he could not shake the fear that our earth is 'An atom' (8.18) in the void profound of unessential Night." 2 David Quint notes 
Leonard's discoveries in his treatment of falling bodies in a network of epic poems, but suggests that Milton contains the most frightening aspects of the Lucretian universe in the well-bounded realm of Chaos, over which God ultimately presides. Still, pointing out that Milton has written about Lucretian doctrines since his youth, Quint finds in Paradise Lost an "anxious preoccupation with the De rerum natura," and suggests that "Milton's doubts and fears may have run deeper, and he may have admitted the force of Lucretius's naturalistic arguments."3

The present study seeks not to counter arguments about falling atoms and Lucretian chaos in Paradise Lost, but to balance them by focusing on other loci of comparison between the two poems. My argument is twofold: first I explore instances of harmony between the two philosophical epics, and next I provide a counterexample to Milton's anxious ambivalence about materialism. This is Milton's treatment of mortalism, another doctrine his age received from Lucretius, and one which the text of Paradise Lost rejects with considerably less ambivalence. ${ }^{4}$ Tracing Milton's treatment of the Lucretian doctrine of annihilation through the poem, I will argue against giving Lucretius a privileged status of infamy among the many ancients on whom Milton drew. Milton engages Lucretius in Paradise Lost as he does many other ancient poets - and indeed as Lucretius does other epic poetsas a respected colleague whose argument had much in common with his but was finally aberrant.

Both Paradise Lost and De Rerum Natura maintain a dialectic between the "light" of truth and the "darkness" of falsehood. Lucretius desires to dispel the darkness of Religio with the light of Epicureanism, and Milton desires to assert the light of Eternal Providence against the threat of falsehood, whether pagan, papist, or atheistic. Philip Hardie has observed that both poets strive energetically "to convert readers from their previous state of mental darkness by a constant engagement with and exposure of error," and in these epics more deliberately than in others. ${ }^{5}$ In other words, both poems fall squarely within the ancient genre of philosophical discourse that "educates" in the etymological sense of the term, leading readers out of the darkness of ignorance. Light figures prominently in both poets' invocations. ${ }^{6}$ Both proceed further to parse their "light" in what might aptly be called the poems' "vision statements." Lucretius repeats the following lines several times over the course of the De Rerum Natura:

Clara tuae possim praepandere lumina menti,

Res quibus occultas penitus convisere possis.

Hunc igitur terrorem animi tenebrasque necessest

Non radii solis neque lucida tela diei 
Discutiant, sed naturae species ratioque. (1.144-48, 2.55-58, 3.87-90, 4.35-38)

That I may be able to shed on your mind so clear a light

So that you can thoroughly scan hidden things,

It is necessary, therefore, that this terror and the shadows of the mind

Should scatter - not by the rays of the sun, nor by the clear shafts

Of daylight, but by the outward appearance and inner system of nature.

Lucretius makes it clear that he is interested not in literal light, but in the figurative light of his Ratio, the system of understanding the cosmos as no more than matter and void. Indeed, Ratio is in Lucretius's world as significant and comprehensive as the "Holy light" is in Milton's. Ratio accomplishes the highest good possible for men: their liberation from the tyranny of Religio, a false system of beliefs that gives rise to much evil.

Milton's similar downplaying of "lucida tela diei" in favour of light from another source is found in some of his most famous lines:

Thus with the year

Seasons return, but not to me returns

Day, or the sweet approach of ev'n or morn,

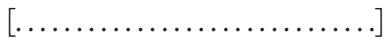

So much the rather thou celestial Light

Shine inward, and the mind through all her powers

Irradiate, there plant eyes, all mist from thence

Purge and disperse, that I may see and tell

Of things invisible to mortal sight. (3.40-42, 51-55)

Hardie has already noticed the thematic affinity between these passages, but he does not mention the lexical similarities: the mind, radiation, the dispersal of mists and shadows. Unsurprisingly, Milton's "truth" and Lucretius's are antithetical: Milton wants to illuminate the spiritual realities that Lucretius views as "shadows of the mind" and seeks to scatter.7 But both poets render explicit the goal of all didactic discourse - to enlighten readers on moral truth - a goal that none of Milton's classical forebears, Lucretius excepted, sets out to accomplish through an epic poem.

It would appear, then, that Clyde Murley's pronouncement, that Milton and Lucretius set out with similar subject matter, is not only accurate; to it can be added the observation that they use like strategies to treat like subjects. ${ }^{8}$ Indeed, the two texts under discussion here are arguably the best-known examples of the didactic epic in the western tradition. The epics of Homer and Virgil are Paradise Lost's most prodigious forbears, but the label "great argument" fits Lucretius's poem better than any of these. Conversely, among the great arguments produced by the classical world, 
Lucretius's is the most epic in form. ${ }^{9}$ Milton probably did not conceive of Paradise Lost as exactly the sort of poem Lucretius had composed in De Rerum Natura; on the other hand, he might have seen a family resemblance more clearly than do many modern readers. When Lucretius appears in Of Education, he is listed with other Greek and Roman poets classed as "those Poets which are now counted most hard," for whom any other unifying trait is difficult to pin down. Nicander and Aratus wrote on technical and prosaic subjects, but Orpheus, usually glossed as the supposed author of Lithica, was also the supposed author of a theogony; and since Milton followed his name with Hesiod's, it is likely that Milton had in mind the two poets' sweeping narratives of beginnings in listing them with Lucretius. ${ }^{10}$ Milton certainly associated Lucretius with beginnings, and particularly that of the human race, ${ }^{11}$ an event that falls outside the scope of the Homeric and Virgilian epics.

Such generic similarities should surely be taken into account in considering Milton's engagement of Lucretius, and the more so when looking for anxiety in that engagement. It bears noting, for instance, that in including De Rerum Natura in Of Education Milton assumes that exposure to Lucretius will not corrupt the youth. Perhaps the age's peculiar mistrust of Lucretius was outweighed in his mind by his general conviction that, when a text thoughtfully considers the nature of things in good Latin, much may be gained by giving that text one's attention. Milton tried to gain still more by employing Lucretius's obviously compelling strategy in the service of his own Christian vision.

Milton may also have noted that Lucretius himself had ample cause for "anxiety," if the term denotes an inability to reconcile every part of his argument with every other part in a logical way. There is a much-documented strain between the content and form of De Rerum Natura: between the tenets of Epicurean materialist philosophy and the evangelical mode in which Lucretius presents them. ${ }^{12}$ Taken to its logical conclusion, such materialism is deterministic, precluding the need for deliberative rhetoric; believing that his readers could choose to be Epicureans, Lucretius had to believe that his readers could choose. This tension was evident in Lucretius's day as well as Milton's. It forced Lucretius to introduce the famous clinamen, the swerve of atoms of their own accord, into his narrative of first things:

[Si] nec declinando faciunt primordia motus principium quoddam quod fati foedera rumpat, ex infinito ne causam causa sequatur, libera per terras unde haec animantibus exstat, unde est haec, inquam, fatis avulsa voluntas per quam progredimur quo ducit quemque voluptas 
declinamus item motus nec tempore certo

nec regione loci certa, sed ubi ipsa tulit mens? (2.253-54, 256-60)

If no first bodies make a certain beginning of motion by swerving, which bursts the laws of fate - so that cause may not follow on cause all the way back from infinity - whence comes for living things throughout the earth, whence, I ask, is this free voluntas torn away from fate, whereby we step forward wherever pleasure leads each one, and likewise incline our motions neither at a fixed time nor to a fixed place, but where the mind itself has borne us?

Epicurean philosophy rejects the idea that humans have no voluntas, no immediate control over their own actions. ${ }^{13}$ Lucretius's belief in random chance, like the ancient doctrine of all-powerful Fate, does not for him preclude immediate agency. This Lucretian inconsistency provoked controversy during Milton's time, just as Milton's own simultaneous acceptance of eternal chaos and eternal providence would do in subsequent centuries.

The tension in Lucretius's particular formulation of materialism would have stood out with great clarity in seventeenth-century England, where atomistic philosophy_ and natural science in general — was seen as posing a threat to Christian doctrine. Many who felt this threat responded by reading Lucretius firsthand, along with other members of the mechanistic faction, and wrote natural theologies pointing out inconsistencies internal to that faction. During the middle of the century, the Cambridge Platonists made an effort in this direction in claiming atomism for Christianity. ${ }^{14}$ Then, in 1675 , natural theologian John Wilkins made an implicit distinction between Lucretius and contemporary atheists. Wilkins cited the former as an ally, making little or no apology for the alliance. ${ }^{15}$ Toward the end of the century, Richard Bentley and John Ray would cite inconsistencies in Lucretius in particular as evidence of the atheists' failure to provide a cogent argument. ${ }^{16}$ Such close attention was bound to tease out the differences between Lucretius and the great contemporary atheist, Thomas Hobbes, who was far less an "evangelist" than was the first-century Epicurean. In Hobbes's view, volition is understood to be "decaying sense"; and human fear of death, though misguided, is a necessary source of order in the commonwealth. ${ }^{17}$ This more reductive materialism poses a greater challenge to conceptions of a meaningful universe than Epicurean materialism does. Lucretius, for all his infinitely falling atoms and dark, limitless universe, runs the risk of accidentally affirming life, rhetorically, in affirming the Epicurean life over others.

Milton and Lucretius not only argue for their prescribed world views by similar means; the world views themselves also have much in common. Granted, what John 
Leonard calls "the doctrinal gulf that separates the two poets"18 cannot be explained away. Still, Lucretius and Milton spend considerable effort inveighing against the same things. The following passage, for example, lists the contents of the limbo of vanity in Paradise Lost:

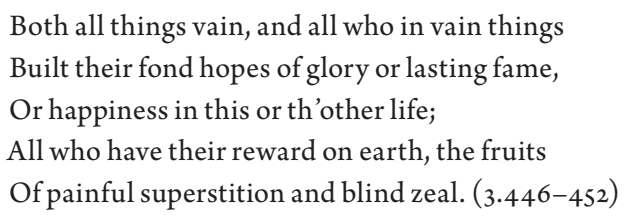

Lucretius's attitude toward individuals who strive to advance themselves through "painful superstition and blind zeal" is identical to that expressed in the above lines. Lucretius views superstition and ambition as undesirable because they prevent securitas, his translation of the Epicurean ideal of ataraxia, a state lacking trouble or confusion. Political ambition is a particular target: in the De Rerum Natura it is Sisyphean and pointless; in Paradise Lost it is diabolical. ${ }^{19}$

The most obvious enemy shared by Milton and Lucretius, however, is not ambition but superstition. Lucretius repeatedly denounces Religio, the superstitious belief in pagan mythology, which he personifies as a malign monster who has long held humankind underfoot, and whom Epicurus bravely dared to challenge. Religio for Lucretius denotes belief in the gods' involvement in human lives, the soul's immortality, and impending judgment. Accordingly, among Lucretius's repeated refrains is a refutation of the view that gods may be touched by human affairs, ${ }^{20}$ a refutation that challenges the epic tradition that was exemplified by Homer and carried on by Lucretius's contemporary, Virgil. ${ }^{21}$

Lucretius's epideictic treatment of Agamemnon and Iphigeneia explains and conveys his evangelistic urgency. For the Epicurean, submission to the gods is not only a waste of time; it also leads to dire consequences. Relating how Agamemnon slaughtered his own daughter so that his fleet might have an auspicious voyage, Lucretius points out that such devotion can lead to cruel and horrible deeds. He opens his discussion, "Aulide quo pacto Triviai virginis aram / Iphianassai turparunt sanguine foede ductores Danaum delecti, prima virorum.” (Thus was the case at Aulis when the chosen leaders of the Greeks, the first among men, foully defiled the altar of the virgin goddess of the crossroads [Diana] with the blood of Iphianassa). ${ }^{22}$ The girl, who has been told that she is to be wed, sees her "sorrowing parent" (maestum parentem), and not her promised bridegroom, standing beside an altar (DRN 1.82-101). While her countrymen shed tears nearby, her father delivers the death stroke that stains the altar with her blood. This unpleasant scene-the 
blood-stained altar, the morose parent, the crying onlookers - is the result of fear of the gods. Lucretius would have his readers understand that the myths familiar to his readers are not only untrue; they are also dangerous. Belief in them leads to atrocities such as Agamemnon's slaughter of his daughter and other such scelerosa atque impia facta, a paradoxical phrase that captures the moral weight Lucretius gives to one's stance toward Religio (1.83).

That Milton likewise felt one's stance toward Religio belief to be of utmost importance will not surprise. What does surprise is that Milton likewise condemns it. In some cases, this does not cause much difficulty: the Greco-Roman pantheon are not the same as the Christian God, as Milton is at pains to demonstrate, and in this way Lucretian deprecation of pagan devotion fits well into Paradise Lost. ${ }^{23}$ But Milton faces a danger of throwing the baby out with the bathwater in condemning wholesale any devotion to a higher power as Lucretius does. In a moment I shall consider more closely how he attempts to negotiate this tension in his epic; at present, it bears mentioning how he does not. He does not make any attempt to establish that the kind of devotion shown by Agamemnon would have been praiseworthy if only done in the service of the right God. He could easily have done so: he was familiar with Aeschylus's and Euripides's accounts of the Iphigeneia episode, neither of which make Agamemnon a murderer. The latter of these, in fact, relates that a deer miraculously appeared in Iphigeneia's place as soon as the blow was struck, bringing to mind the story of Abraham and Isaac in Genesis 22. ${ }^{24}$ Milton leaves this event out of Michael's account of Abraham in Paradise Lost 12, nor does such an act of sacrifice appear in good light anywhere else in the epic.

Instead, Milton condemns this behavior just as Lucretius does, describing child sacrifice as a ghastly spectacle practised by those who are cowed into false religious devotion. In a colourful passage in Book 1, Milton depicts the future behavior of Moloch's worshippers:

\footnotetext{
First Moloch, horrid king besmeared with blood Of human sacrifice, and parents' tears, Though for the noise of drums and timbrels loud Their children's cries unheard, that passed through fire To this grim idol. (1.392-96)
}

Here, just as in De Rerum Natura, human fear of the god leads to the shedding of innocent children's blood before the eyes of grieving parents. The lack of any mention of the Abraham episode to balance this is significant: the rhetoric of Paradise Lost does not send the conflicted message, "Religio is evil except in the service of the Christian God." The message seems rather to be, "service rendered to the Christian 
God will never look like Religio.” This message, moreover, is not delivered in an anxious way. Milton makes the point with his usual ardour to expose and decry crooked behaviour. If the De Rerum Natura provides a good model of such censure, then Milton will import Lucretian wisdom into Paradise Lost just as he would Homeric or Virgilian or Platonic wisdom. Just as, for example, Milton rhetorically praises the pietas condoned in the Aeneid but finally portrays that pietas as needing redirection, he likewise rejects superstitious devotion (as does the De Rerum Natura) but takes care to distance that devotion from Christian faith.

How does Milton maintain this separation, which Lucretius would find absurd? The answer may be found in the poets' differing treatment of pagan mythology. Lucretius, for whom pagan gods are "the gods," redefines them so as to render them unrecognizable as the pantheon familiar to his audience. They live in a state of perpetual securitas, utterly unconcerned with the affairs of humans, composed of particles so tenuous that interaction between them and ourselves is impossible. ${ }^{25}$ Lucretius fights two great enemies: fear of death and fear of the gods. Fanciful stories that give rise to and feed such fears, therefore, are to be shunned-or, better, deployed in the service of his Epicurean message. One should not believe that humans really go to afterworlds such as Elysium and Tartarus, he says; rather, "Ea [ ... ] quaecumque Acherunte profundo / prodita sunt esse, in vita sunt omnia nobis" (3.978-79). [Whatever things are given to be in the depths of Acheron, are all in our life.] That is, the stories that tell of commerce between our reality and the world of spirits are useful only as allegory.

Lucretius spends some time illustrating this principle in De Rerum Natura 3: "Sed Tityos nobis hic est, in amore iacentem / quem volucres lacerant atque exest anxius angor / aut alia quavis scindunt cuppedine curae" (3.992-94). [But this is our Tityus: the one whom, lying in love, the vultures tear-and whom anxious anguish eats - or whom other cares ravage with some passion.] The real Tityus, he insists, does not really reside in an unseen underworld. He is only the forlorn man who has not paid attention to the Epicurean injunction against falling in love and now wastes his life worrying about the welfare and constancy of his beloved. Likewise, the real Sisyphus does not literally roll a stone up a hill in Tartarus; he is only the vainly ambitious politician: "Sisyphus in vita quoque nobis ante oculos est / qui petere a populo fascis saevasque securis / imbibit et semper victus tristisque recedit" (3.995-97). [Likewise, a real, live Sisyphus is before our eyes: the man who always thirsts to seek the fasces and terrible axes from the people, and always returns gloomy and defeated.] In each case, Lucretius pointedly strips the myth 
of its efficacy to inspire fear of punishment in the afterlife, leaving only the moral interpretation.

Milton's hell, too, is often read as allegorical, but next to Lucretius's Tartarus it looks quite real. Granted, Moloch, Belial, and Mammon are open to allegorical interpretation-Moloch figures wrath; Belial, sloth; Mamon, greed, and so on - but nowhere does Milton insist that they must be so interpreted, nor does his description of their future interaction with mankind seem geared toward disillusioning his audience of their existence. ${ }^{26}$ On the contrary, Milton often describes ancient myth as too mundane. His biblical subjects are "great things" compared with the smallness of pagan mythology. For Lucretius, the myths themselves are too fantastic - too "great" - to be accepted at more than an allegorical level by anyone who apprehends his Ratio. This discrepancy sets Milton at a rhetorical advantage over Lucretius: Lucretius scales down the stories about benign and malevolent deities to make the point that actions such as the slaughter of Iphigeneia are senseless; Milton suggests that these beings are enemies of God bent on human ruin, making such actions sinful and ultimately self-destructive. The two poets write for different stakes. Lucretius wishes to indoctrinate his readers because this serves the Epicurean telos of minimizing pain and maximizing pleasure in the present life. ${ }^{27}$ Milton writes toward the Christian telos of "One Kingdom, Joy, and union without end" in the hereafter ( $P L$ 7.161).

It is important to note that this ontological distinction between Lucretius's pagan myths and Milton's is a matter of relativity: both poets want to have their cake and eat it too, capturing the imaginative appeal of those stories without also deploying their rhetorical thrust by accident. The literal/allegorical binary I have been implying thus does not do justice either to Milton or to Lucretius. Regarding Milton, such a binary oversimplifies a much commented-on ontological hierarchy that ascribes "degrees of substance" to every entity according to its perfection. Some creatures - irrational animals, plants - are born less substantial in Milton's cosmos, but many achieve such ontological impoverishment or have it thrust upon them. These are the beings who willfully choose to do evil rather than good, a group that would include Diana as well as Moloch in the world of Paradise Lost. Lucretius's Diana, by contrast, has not earned her ontic privation by rebelling against God; she is merely ephemeral by nature. In both epics a relationship emerges between solidity — not to say materiality, for both poets are monists — and moral rightness. The key difference is that, for Milton, the relationship is direct, while for Lucretius, it is inverse. Lucretius does not merely proscribe the literal reading of myths. In his own materialist universe the gods, who live in perpetual securitas, are more tenuous 
and rarified than the creatures comprising the visible world. Significantly, the gods so described are not deprecated but held up as a model for how humans ought to pass their brief time of existence. Milton's epideictic runs opposite to Lucretius's on both counts. Milton not only weaves the doctrine of evil as privation into his narrative; he also uses allegorical personifications to indicate deficient ontology. ${ }^{28}$

This may seem counterintuitive: how can it be that the "Epicure" rhetorically privileges a wispy plane of existence while the neoplatonic Christian privileges that which is more solid? But this paradox quickly sorts itself out upon further reflection. To begin with, Lucretius was no "Epicure." Nor, for that matter, was Epicurus. To the true Epicurean, existence and non-existence is all one; what must be avoided at all costs are the pernicious beliefs that cause mental unrest and physical pain to oneself and others: fear of gods, fear of death. Milton famously causes equal and opposite trouble for those who wish to characterize him as a Christian ascetic, particularly in his positive treatment of sexual intercourse at two different levels of the cosmic hierarchy in Paradise Lost 4 and 8. At bottom, however, this difference between the two poets' rhetorical strategies is not a matter of their attitudes toward food and sex. Milton's correlation of ontic status with perfection, inherited from a long line of Christian thinkers, ${ }^{29}$ is utterly compatible with his Christian convictions: the Creator, characterized by the highest perfection and goodness, confers that perfection and goodness to the extent that He creates. This stands in direct opposition to Epicurean doctrine. In Lucretius's universe, to create-were it possible-is not better than created to destroy.

This brings us to the final locus of comparison between the two poems: their treatment of the afterlife. Considerations of Lucretius's presence in Paradise Lost typically focus on chaos, the vast stretch of space, without also noting Milton's treatment of the vast stretch of time, which was equally important in the two poets' cosmologies. In the Lucretian cosmos, where every possible world will necessarily conglomerate an infinite number of times out of the collection of indestructible atoms, human consciousness is a fleeting occurrence. From the human point of view, this is best expressed in the Epicurean axiom that death closes all. The most famous line of De Rerum Natura thus begins, “Therefore, death is nothing to us" (3.830). [Nil igitur mors est ad nos.] Lucretius goes on to speak as Natura in an accusing tone:

Quid tibi tanto operest, mortalis, quod nimis aegris

Luctibus indulges? Quid mortem congemis ac fles?

Nam si grata fuit tibi vita anteacta priorque

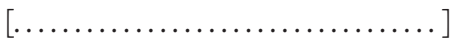

cur non ut plenus vitae conviva recedis

aequo animoque capis securam, stulte, quietem? 
sin ea quae fructus cumque es periere profusa

vitaque in offensast, cur amplius addere quaeris? (3.933-35, 938-41)

What is so troublesome to you, o mortal, that you indulge too much in

Anxious lamentations? Why do you groan and bewail death?

For if your past and former life was pleasing to you [ ... ]

Why do you not depart like a banqueter who is sated with life,

And embrace untroubled quiet with a calm mind, you fool?

But if those things which you enjoyed have been poured out and perished,

And life is hateful, why do you seek to add more? 30

In combating such a widespread phenomenon as the fear of death, Lucretius needed to be thorough and emphatic: later in the same book, he censures people who, in looking ahead to death, worry about the welfare of loved ones who are left behind; he points out that the dead no longer exist, and so cannot perceive how the living fare (3.894-903). He is not merely urging that people stop fearing the inevitable; he is elevating death's worth and desirability to the point where it is on par with life, an even substitution.

It is unclear precisely what Milton thought happened to the soul at death, ${ }^{31}$ but in Paradise Lost he rejects the doctrine of total annihilation. ${ }^{32}$ Norman T. Burns, who elsewhere avers that Milton's mortalism is no less heretical than that of Hobbes, ${ }^{33}$ concedes that Paradise Lost takes the orthodox position, pointing out that the poem is explicitly immortalist:

In Paradise Lost, X, 782-792, the fallen Adam, whom Michael has not yet told of the General Resurrection and the Judgment, reasons out that God's sentence of death must also apply to the soul [ ... ]. Milton may not, of course, have thought it appropriate to propound such a disputable doctrine as mortalism in his poetry; thus the immortalism of his verse is no certain evidence of his beliefs. (169)

The passage that Burns cites is a crucial one, and we shall see in a moment that Milton probably had Lucretius in mind when he wrote it. Here the point is that the mortalist position arises in the poem only to be rejected. In fact, throughout the poem any suggestion of devaluing life or overvaluing death as Lucretius does in De Rerum Natura 3 is suspect, tied to perverted thinking. Milton's stance is hardly surprising: such inversion is heretical, evincing both contempt for God's gift of life and idolatry of death, the undesirable consequence of sin. But the frequency and candour with which Milton invokes Lucretian views of death invite attention.

References to annihilation, or at least the possibility of annihilation, arise throughout Paradise Lost. The actuality, as Lucretius knew well, would cast serious doubt on God's omniscience and providence. Thus does the Son reject as a possible 
solution for the Fall the annihilation of humans: "Or wilt thou thyself," he asks his Father, "Abolish thy creation, and unmake, / For him, what for thy glory thou hast made?" (3.162-64). To do so, the Son points out, would be as much a victory for Satan as would the damnation of the entire race. Meanwhile in hell, Beelzebub follows the same logic when he sets forth his scheme for the invasion of the new world, expressing hope that God will have to "abolish his own works," the scenario the Son has rejected (2.370). Adam, too, reasons himself to this conclusion just before he eats the fruit (9.938-51). Annihilation of angelic beings is considered as well. Moloch brazenly invites their own annihilation, claiming that such would be an easy price to pay for the potential glory of open war on heaven-Belial squeamishly draws back from the idea - and Satan mentions annihilation as the possible fate of anyone who dares to journey through a suspiciously Lucretian chaos that "with utter loss of being / Threatens" (2.440-41). Lucretian anxiety, then, certainly haunts Satan and his followers, whether or not it haunted Milton.

Lacking the ability to distinguish between annihilation and mere bodily death, prelapsarian man nonetheless praises life and impugns death, whatever it may be. Adam relates to Raphael that, when he was first created, he found himself joyful to be alive, linking his existence with the "goodness and power" of God:

\author{
'Thou sun,' said I, 'fair light,'

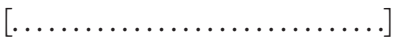 \\ Tell, if ye saw, how came I thus, how here? \\ Not of myself; by some great Maker then, \\ In goodness and in power preeminent; \\ Tell me, how may I know him, how adore, \\ From whom I have that thus I move and live. $(8.273,277-81)$
}

Adam and Eve are repelled by the idea of disobeying God's command, not only because of their natural fealty to his commands, but also because of their natural trust that what he says is bad is, in fact, bad. Not fully understanding what death is, Adam briefly pronounces to Eve that death is "some dreadful thing no doubt" (4.427). The wisely dreading Adam stands in stark contrast to the more Epicurean Satan: from Book 1 Satan has been "unmoved / By fear of death" (1.554-55).

At the moment of the temptation, the serpentine Satan works to impart his attitude to Eve. Asserting that he has eaten the fruit and gained the faculty of speech, he declares that death is "to be wisht, / Though threat'nd, which no worse than this can bring" (9.714-15).34 And again, in a particularly convoluted line, he reasons "Your feare it selfe of Death removes the feare" (9.702). Among his other circumlocutions, then, Satan spends considerable effort exonerating death. 
Satan's effort pays off: in their fall, both Adam and Eve completely reverse their views about death, adopting the Epicurean position. In offering the fruit to Adam, Eve urges him to deliver his fear of death to the winds (9.989). And Adam, once fallen, is ready to surrender himself to annihilation: his desire to know and adore his maker has been replaced by an accusation against God that he did not ask to be created. "It were but right," he protests, "And equal to reduce me to my dust, / Desirous to resign, and render back / All I received" (10.747-50). A few lines later, he has "oft / Cursed his creation, Death as oft accused / Of tardy execution" (851-53). He has lost his gratitude for God's gift of life and, like Lucretius's Natura, sees the end of his existence as desirable. A little while later, he contemplates the horrible prospect that he might survive the death of his body, reasoning that this cannot possibly be the case:

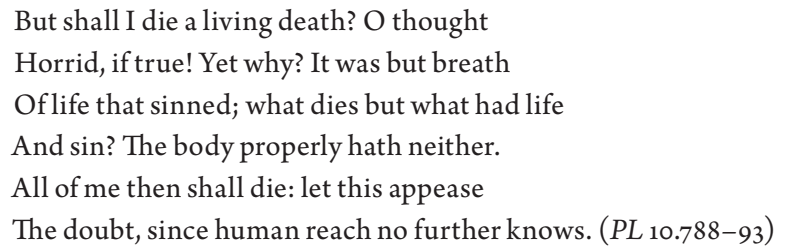

Continuing in this vein, Adam asks rhetorically, "Can [God] make deathless death?" (10.798). This question is problematic at more than one level: Adam expresses not only a depraved desire for death, but also a misguided belief that God, not Sin, is Death's author. 35

This second formulation of the question in particular highlights Lucretius's presence in Adam's argument for mortalism. The substitution of "deathless" for "living" a few lines earlier calls to mind these lines from the De Rerum Natura:

Scire licet nobis nil esse in morte timendum

$\mathrm{Nec}$ miserum fieri qui non est posse neque hilum

Differre an nullo fuerit iam tempore natus,

Mortalem vitam mors cum immortalis ademit.

\begin{abstract}
It is profitable for us to know that there is nothing to be feared in death, nor can the one become wretched who does not exist, nor does it make one whit of difference whether he was never born, when deathless death has taken away mortal life. (DRN 3.866-69)
\end{abstract}

The recently fallen Adam would have been comforted indeed to hear these words. The seemingly paradoxical "mors immortalis," death that does not die, is a turn of phrase for which Lucretius is famous. ${ }^{36}$ In the passage in Paradise Lost that deals 
most explicitly with the topic of mortalism, then, Milton translates a rhetorical device used by Lucretius in his discussion of the same subject. But the fallen Adam intends "deathless" to refer to the state of his own soul and not of death itself. While Lucretius's text asks readers to consider the paradox of death's immortality, Adam finds a logical inconsistency in the idea that anything besides annihilation could properly be termed "death."

Even the repentant Adam has trouble understanding with his fallen reason that the death he will suffer does not amount to annihilation. It seems that Milton wanted to emphasize this, or perhaps, as Campbell suggested, that he gradually departed from the radical mortalism of De Doctrina Christiana during his later years. He made only two significant additions to the 1674 Paradise Lost text that did not serve to smooth out the new transitions between books, and one of these comes during Adam's pronouncement to Michael after the two observe death and old age:

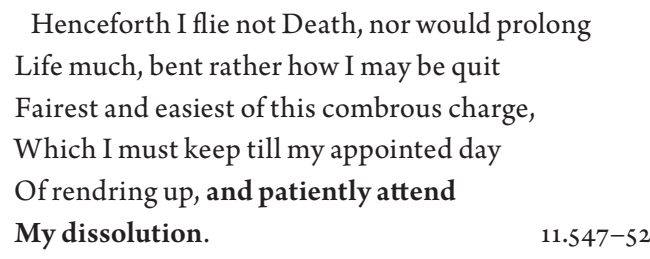

Before this emendation, Adam might be read as understanding that death of the body will free his immortal soul, but the 1674 text leaves no room for this interpretation. Adam has just seen his descendants ravaged by disease and old age-in fact, Milton's other substantial emendation was to add three more lines of diseases to this listand in this context dissolution is the best end he can imagine, until Michael has explained to Adam the redemptive effects of the cross. The same misunderstanding will plague his unbelieving descendants.

As it turns out, however, Adam was more truthful than he knew when he reasoned that there is no such thing as "deathless death." His question invited a negative answer: surely, he said, not even God is capable of the logical inconsistency of a "deathless death." And, while he was wrong to conclude that his soul must therefore die with his body, "deathless death" in the Lucretian sense - that is, death that cannot itself die-is impossible in the Christian world of Paradise Lost. After serving his preordained purpose as the "gate of life" (12.571), Death will, along with Sin and Grave, "at last / Through Chaos hurled, obstruct the mouth of Hell / For ever" (10.635-37). Paradise Lost rejects the solace of Lucretius's mors immortalis, then, in favor of a promise that life will one day be renewed and will no longer seem 
loathsome to humans. For Lucretius, death is without sting because no one remains to be stung; for Milton, this sting will ultimately be turned onto death itself.

Alongside Milton's possible anxiety over a Lucretian materialist universe, then, we have to consider his readiness to align himself with Lucretius against pagan religious devotion, and Lucretius's own cause for anxiety: the tensions already present in De Rerum Natura, which sometimes invests human decisions with meaning while arguing for a meaningless world. We should also admit into the discussion Milton's unabashed polemic against mors immortalis. If, as Quint says, Milton’s “unease with the Epicurean doctrine he confutes is measured by the very indirectness of his approach to it," we find in Milton's head-on treatment of Lucretian mortalism evidence of his confidence regarding the wrongness of that doctrine. ${ }^{37}$ If Lucretius's bleak, black universe overcomes Milton's attempts to expel it and "creeps back in his despite," as Leonard argues, ${ }^{38}$ Lucretius's immortal mors is let in the front door, only to be dealt a fatal blow.

\section{Notes}

1. Clyde Murley, "Lucretius, De Rerum Natura, Viewed as Epic," in Transactions and Proceedings of the American Philological Association, 78 (1947), p. 336. Many thanks to Julia Dyson, Phillip Donnelly, Dennis Danielson, and Stephen Guy-Bray for reviewing this essay in manuscript. The Latin edition of Lucretius cited here is Cyril Bailey's (Oxford: Clarendon Press, 1947); the edition of Hobbes's Leviathan is J.C.A. Gaskin's (Oxford: Oxford University Press, 1998). Translations from Latin are mine unless otherwise indicated.

2. John Leonard, "Milton, Lucretius, and 'the Void Profound of Unessential Night," in Living Texts: Interpreting Milton, ed. K.A. Pruitt and C.W. Durham (Selinsgrove, PA: Susquehanna University Press, 2000), p. 211.

3. David Quint, "Fear of Falling: Icarus, Phaethon, and Lucretius in Paradise Lost," Renaissance Quarterly 57.3 (2004), pp. 859-60, 870-71.

4. Raymond B. Waddington touches on the likelihood that Milton's engagement with mortalism was sparked off by Lucretius in particular, in "Murder One: The Death of Abel: Blood, Soul, and Mortalism in Paradise Lost," (Milton Studies 41 [2002], pp. 7693), p. 85, citing Phillip Hardie.

5. Phillip Hardie, "The Presence of Lucretius in Paradise Lost," Milton Quarterly 29.1 (1995), p. 18.

6. Milton's “Hail holy light, offspring of Heav'n first-born, / Or of th' Eternal coeternal beam" (3.1-2) leaves open the question of light's origin, as does Lucretius's "Nec sine te [Venus] quicquam dias in luminis oras / Exoritur" (1.23-24); both, however, make clear that "bringing to light" is a fundamental good, enabled or embodied by the invoked deity. 
7. Hardie has this discrepancy in mind when he points out that “[Milton's] 'things invisible to mortal sight' are of a different order from the invisible atoms that Lucretius will present to the mind's eye" (p. 18).

8. In Milton Among the Philosophers: Poetry and Materialism in Seventeenth-Century England (Ithaca: Cornell University Press, 1991), Stephen M. Fallon mentions, but does not discuss, this generic similarity: "Milton, in setting out to write an epic of heaven, the world, and hell, committed himself to an expansion of Genesis and an exploration, in the tradition of Lucretius, of the way things are" (p. 15).

9. Monica R. Gale points out that, by the time Lucretius was writing, prose had long been the medium of choice for philosophers, making his choice to use poetry rather unusual. See Gale's Lucretius and the Didactic Epic (London: Bristol Classical Press, 2001), p. 6.

10. It is probably for this reason that Laura E. Lockwood claims, in her 1911 edition of $O f$ Education (Boston: Houghton Mifflin Co.), that Orpheus's Theogony is the text most likely referenced here.

11. See Merrit Y. Hughes's note on Paradise Lost 5.503: "Whose progeny you are," points out that Milton "found corroboration for the thought in Lucretius' materialistic derivation of all life from 'one celestial seed' in De rerum natura ii, 991-92," which yoking is evident in Milton's annotations on Aratus (Hughes, Complete Poems and Major Prose [New York: Odyssey Press, 1957]). See Maurice Kelley and Samuel D Atkins, "Milton's Annotations of Aratus," PMLA 70 [1955], pp. 1090-1106.

12. The question of whether Lucretius was a poet, a philosopher, or both was famously taken up in the nineteenth century by H.A.J. Munro ("On Mrs. Lucie Hutchinson's Translation of Lucretius," The Journal of Classical and Sacred Philology 4 [1858], pp. 121-39), next by critics such as T.S. Eliot (Selected Prose of T.S. Eliot, ed. Frank Kermode [New York: Harcourt, Inc., 1975], pp. 86 ff.) and Cyril Bailey ("The Mind of Lucretius," American Journal of Philology 61.3 [1940], pp. 278-91), and later by C.J. Classen ("Poetry and Rhetoric in Lucretius," Transactions and Proceedings of the American Philological Association 99 [1968], pp. 77-118), and Elisabeth Asmis ("Rhetoric and Reason in Lucretius," American Journal of Philology 104.1 [1983], pp. 36-66). More recently, recognizing the fact of his evangelical urgency, Monica R. Gale suggests that the question has outlived its usefulness:

It seems pointless to ask whether Lucretius was first a poet in search of a theme or an Epicurean in search of a means of communicating his faith; so far as the

De Rerum Natura ... is concerned, poetry and philosophy are completely intermeshed. (8)

The same two voices — of poet and philosopher-are present in Paradise Lost, as Fallon discusses in his introduction to Milton Among the Philosophers.

13. Modern readers often find themselves frustrated by the extent to which various "competing" higher forces and human volition coexist in classical texts. Julia Dyson has shown how the Roman historian Livy, for example, employs "forte quadam divinitus" 
(by chance, through divine agency), two phrases now seeming logically inconsistent, in his narration of the lives of Romulus and Remus (Ab Urbe Condita 1.4.4, quoted in a paper presented at the UvA Colloquium on Roman Religion in April 2005). For a detailed account of how Lucretius's clinamen functions to facilitate free will, see D.P. Fowler in Lucretius on Atomic Motion: A commentary on De Rerum Natura Book 2, Lines 1-332 (Oxford: Oxford University Press, 2002).

14. In their view, atomism had been falsely conflated with atheism and a wholly mechanistic understanding of the universe, although they admitted that the association of one with the other dates back to Epicurus himself. Cudworth goes so far as to proclaim that, far from proving atheism, atomism is "the most effectual Engin against Atheism that can be" (True Intellectual System I, vii, qtd. in Fallon, p. 57).

15. Like a number of natural theologians, Wilkins sometimes cites Lucretius precisely because points conceded by the opposition carry all the more weight. But sometimes Lucretius is just another ancient authority: when Wilkins explains, for example, that the brevity of recorded history "was that which convinced Lucretius, that the World could not be Eternal," Wilkins finds necessary neither to defend Lucretius as an acceptable authority, nor to insist that much of Lucretius's thought—-though not thisis to be rejected (The Principles and Duties of Natural Religion [1675], p. 71).

16. Lucretius's answer to the question "where did atoms come from?" Bentley translates somewhat strongly, "no body knows why, nor when, nor where" (nec regione loci certa, nec tempore certo [DRN 2.259-60]) and points out that this non-explanation "contented supine unthinking Atheists for a thousand years together" (The Folly of Atheism [1692], p. 216). He also cites Lucretius's mistrust of poetry as evidence of atheists' fear that they are wrong (pp. 277, 300). Ray quotes Lucretius's famous "swerve" passage, pointing out that this "gratuitous Declination of Atomes" actually solves nothing (Wisdom of God [1691], p. 15).

17. For a succinct discussion of Hobbes's radically mechanistic view of human thought and behaviour, see Fallon, pp. 33-36. Regarding fear of death, Hobbes writes, "The Passions that encline men to Peace, are Feare of Death [ ... ]," in Leviathan, ed. J.C.A. Gaskin (Oxford: Oxford University Press (1998), p. 93. This is a far cry from Lucretius's offer to dispel the terrorem animi by introducing his audience to the Ratio of Epicureanism (DRN 1.146).

18. Leonard, “Milton," p. 199.

19. See for example $D R N$ 3.995-97, PL 2.295-304. It is important to note that neither Milton nor Lucretius viewed kingship as inherently bad: the Son rightly assumed kingship. They did, however, view political ambition as diabolical. For a discussion of the differences between Satan's and the Son's attitudes toward political power, see David Norbrook's Writing the English Republic: Poetry, Rhetoric and Politics, 1627-1660 (Cambridge: Cambridge University Press, 1999), pp. 474-77.

20. DRN 1.44-49, 2.646-51.

21. For a discussion on the philosophical interaction between Lucretius and Virgil in particular, see Julia T. Dyson, “Fluctus Irarum, Fluctus Curarum: Lucretian Religio 
in the Aeneid," American Journal of Philology 118.3 (1997), pp. 449-57 and "Dido the Epicurean," Classical Antiquity 15.2 (1996), pp. 203-21.

22. DRN 1.84-86, Walter Englert (Newburyport, MA: Focus Philosophical Library, 2003), p. 3

23. Hardie has noted a "polemic against mythology" common to both poets (p. 18).

24. Iphigeneia in Tauris. In Euripidis Fabulae, ed. Gilbert Murray (Oxford: Oxford University Press, 1913), 11.25 ff.

25. See for example $D R N 1.44,2.646$ and Gale, p. 12.

26. This is not to say that Milton leaves no room for empty-as opposed to demonicpagan mythology: he often ascribes such emptiness to ancient imaginative works and to vain Christian practice. One thinks of his distinguishing the "not mystic" Old Testament stories from "feigned" and "erring" pagan myths (PL 9.439-43, 4.249-51, 4.705-07), and of Michael's speech:

Heavy persecution shall arise

On all who in the worship persevere

Of Spirit and Truth; the rest, far greater part,

Will deem in outward rites and specious forms

Religion satisfied; Truth shall retire. (PL 12.531-35)

As we have seen in the case of Moloch, however, when "outward rites" contravene God's intention in creation, they appear in Paradise Lost as done in the service of the demonic.

27. This "pleasure," it should be mentioned, is not the unrestrained indulgence of appetite popularly associated with the "Epicure." For the follower of Epicurus, "pleasure" involves instead a tempered practice of minimizing the influence of anxiety-producing agents on one's life. See Julia Dyson, “Dido the Epicurean,” pp. 208-09; and pp. 17-18 of James Warren's Facing Death: Epicurus and his Critics (Oxford: Clarendon Press, 2004) for succinct discussions of this Epicurean telos.

28. For discussion of the Augustinian ontology of evil in Paradise Lost, see the introduction to Dennis Danielson's Milton's Good God: A Study in Literary Theodicy (Cambridge: Cambridge University Press, 1982). On the topic of Milton's use of allegory to represent ontic privation due to evil in particular, see Fallon, pp. 180-83.

29. Exemplary of this is St. Augustine's theodicy, which defines evil as privation.

3o. Englert, p. 87 .

31. Milton's De Doctrina Christiana espouses a heterodox Christian mortalism, arguing not only that human souls die with their bodies (albeit to wake again) but also that even Christ's divine nature died with his body (DDC 1.7, 13, 16). Paradise Lost makes the opposite point ( $P L 3.246,10.782-92$ ). Critics have weighed in on both sides of this issue. See for example William Walker ("Milton's Dualistic Theory of Religious Toleration in A Treatise of Civil Power, Of Christian Doctrine, and Paradise Lost," Modern Philology 99 [2001], pp. 201-30), who asserts that Paradise Lost espouses dualism, and Waddington, pp. 76-93, who argues that one can find a monist mortalism in the bleeding out of Abel's life in book XI. 
32. For a succinct discussion of Milton's movement from heterodox mortalism in De Doctrina Christiana to a relatively more orthodox view in Paradise Lost, see Gordon Campbell, "The Mortalist Heresy in Paradise Lost" (Milton Quarterly 13 [1979], pp.33-36). The present study is in harmony with Campbell's conclusion that "Adam's defense of mortalism was therefore nothing more than an attempt to deny the consequences of his fall, to appease the fear of living death. Only when he denies mortalism and faces the truth of death does he begin to repent" (34). Raymond B. Waddington's illuminating discussion of contemporary Christian materialisms suffers in finally appealing to Christopher Hill's "four mortalist loci” in Paradise Lost, which do not stand up to the criticism offered by Campbell's and other arguments. One of these loci, in fact, is the assertion of mortalism by the fallen and unrepentant Adam.

33. Norman T. Burns, Christian Mortalism from Tyndale to Milton (Cambridge, MA: Harvard University Press, 1972), p. 183.

34. John Leonard highlights this aspect of Satan's strategy, in Naming in Paradise: Milton and the Language of Adam and Eve (Oxford: Oxford University Press, 1990), pointing out that 'Satan's 'whatever thing Death be' dismisses all dread of this pronouncement [of consequent Death]” (p. 202).

35. Fallon, p. 188: "Death would appear to have inherited insubstantiality (and thus nonentity) from Sin. This paradoxical genetic speculation follows from Milton's Augustinian ontology of evil."

36. Bailey calls mors immortalis "a fine antithesis" (DRN, p. 1139). Leonard and Smith, De Rerum Natura (Madison: University of Wisconsin Press, 1942), note the "paradoxical implication that in a world where life is death only death never dies" (p. 497). Both editions note that Lucretius probably draws on Amphis, a Greek comic poet whose works have been lost.

37. Quint, p. 871.

38. Leonard, “Milton," p. 213. 